Soreanu, C. (2021). Artistic strategies in Oliviero Toscani's advertising. Scientific view on the modern problems of cultural heritage and arts in the context of social development. Klironomy, 1 (1), 181-208. Hlučín-Bobrovníky: "Anisiia Tomanek" OSVČ.

Soreanu, C. (2021). Strategii artistice în publicitatea lui Oliviero Toscani. Scientific view on the modern problems of cultural heritage and arts in the context of social development. Klironomy, 1 (1), 181-208. Hlučín-Bobrovníky: "Anisiia Tomanek" OSVČ.

DOI: $10.47451 /$ art2021-04-001

EOI: $10.11249 / \operatorname{art} 2020-04-001$

The paper is published in Crossref, Internet Archive, Google Scholar, Academic Resource Index ResearchBib, JGate, ISI, CiteFactor, ICI, eLibrary databases.

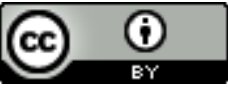

Catalin Soreanu Doctor in Visual Arts, PhD

Lecturer

Specialization Photography, Video, Computer image processing Faculty of Visual Arts and Design "George Enescu" National University of the Arts Iasi, Romania

E-mail: csoreanu@hotmail.com ORCID: 0000-0001-6958-1809

\title{
Artistic strategies in Oliviero 'Toscani's advertising
}

\section{Abstract:}

In this article, we will discuss how contemporary advertising becomes the territory where various artistic expressions contribute in a complementary way to the constitution of the meaning of a work. The case study will approach the activity of Oliviero Toscani, and his two decades of collaboration with Benetton materialized in memorable advertising campaigns that rewrote the visual history of contemporary advertising. We will analyze how photographic media provides advertising with one of the most consistent expressive resources, based on the realism of the image, the endless possibilities in managing the visual composition, the premises of reproducibility and, last but not least, the appetite of an audience eager for the technological image. Also, we will try to discuss the creative premises and mechanisms that characterize Toscani's creation, the reading conditions of his advertising works, as well as how his creative strategies combine the expressiveness of the technological precision of press photography, and the appropriation strategies specific to artistic postmodernity.

Keywords: advertising, Benetton, media, Oliviero Toscani, photography, postmodern.

Cătălin Soreanu

Doctor in Arte Vizuale univ. dr., lector

Specializarea Fotografie, Video, Procesarea computerizată a imaginii Facultatea de Arte Vizuale şi Design 
Universitatea Națională de Arte "George Enescu” Iaşi, România

E-mail: csoreanu@hotmail.com ORCID: 0000-0001-6958-1809

\title{
Strategii artistice în publicitatea lui Oliviero Toscani
}

\begin{abstract}
:
În acest articol, vom discuta despre modul în care publicitatea contemporană devine teritoriul în care diverse expresivități artistice contribuie (într-un mod complementar) la constituirea sensului unei opere. Studiile de caz vor aborda cele două decenii de colaborare a lui Oliviero Toscani cu Benetton, concretizate în memorabile campanii publicitare ce au rescris istoria vizuală a publicității contemporane. Vom analiza modul în care fotografia oferă publicității una dintre cele mai consistente resurse expresive, bazată pe realismul imaginii, pe posibilitățile infinite de gestionare a compoziţiei vizuale, pe premisele reproductibilităţii şi, nu în ultimul rând, pe apetitul publicului avid de imagine tehnologică. De asemenea, vom încerca să discutăm premisele şi mecanismele creative care caracterizează creația lui Toscani, condițiile de citire a lucrărilor sale publicitare, precum şi modul în care strategiile sale creative combină expresivitatea preciziei tehnologice a fotografiei de presă şi strategiile de apropriere artistică specifice postmodernității.
\end{abstract}

Cuvinte cheie: publicitate, Benetton, media, Oliviero Toscani, fotografie, postmodernitate.

\section{Introduction}

The purpose is of this material is to investigate the results of the collaboration between the Italian photographer artist Oliviero Toscani and the Benetton Group company, in terms of advertising strategies, visual solutions, and thematic subjectivity, and to understand what artistic strategies are creatively embodied in the almost two decades of advertising projects. For this initiative, the works made by Toscani for Benetton, provided the necessary support to identify artistic practices that offer specific value to advertising construction, in an approach that transcends the boundary between "art" and "advertising", as visual and cultural disciplines. The methods of research are based on Roland Barthes' semiotic theory of denotation/connotation structure (Barthes, 1977), and also on the dissociation between relational and structural properties of a visual construct, as stated by Mihai Taraşi in his visual compositional theory (Taraşi, 2006). While following a deductionbased investigation method of the case studies' thematic, subject and visual strategies, we will also analyse the way Toscani uses postmodern artistic strategies such as appropriation and resignification, in order to achieve the meaning of the advertising construction, as concluded in my research published in 2018 in "Artă şi publicitate. 
Medii de expresie în publicitatea contemporană" (Art and Advertising. Mediums of expression in contemporary advertising) (Soreanu, 2018). For this, we focused on a case studies corpus based on the works from the final part of the collaboration between Oliviero Toscani and Benetton before 2000s, including the "mature" concepts, in which Toscani pushed the limit of the advertising creative act, with a solution based on the appropriation of images from everyday international realities media, such as images of refugees, war scenes, mafia executions, scenes with illness, the dying, or prison death row inmates. As a consequence, Benetton has become synonymous with the unconventional and innovation in the visual culture of 2000s, due to the involvement of Toscani, who promoted them from national quasianonymity to global brand status, the artist dealing with their corporate image, brand identity, and communication strategy [1].

This article content is oriented toward those sharing an interest in the manifestations of contemporary advertising - particularly Oliviero Toscani's activity while collaborating with Benetton - from educational, academic, professional, or simply general interest areas.

\section{The "Art" in Advertising}

Being recognized both as a remarkable visual artist, and as the creative force behind some of the most successful brands such as Esprit, Valentino, Chanel, Fiorucci or Prenatal, Oliviero Toscani defined advertising photography in terms of his own artistic creation based on the formula of postmodern appropriation, transforming the photographic image into a visual material both appropriated and re-signified through specific aesthetification [2]. The complex creative mechanism that we can identify behind his works is the result of a deep artistic intentionality that doubles the advertising approach, vitiating the very definition of the dependency relationship between the fields of art and advertising. In the context of postmodern art, in which advertising is defined in its visual dimension as an exponent of the consumer area, the type of social-consumer ideology, and derived social behaviours, Toscani's strategy is simple and straightforward: he avoids the clichés characteristic of commercial advertising, moving towards a form of image support in which the subjects no longer have the product as a reference, but the ideology that defines it, and which becomes the main subject of the expressive advertising offer (Sturken \& Cartwright, 2001).

Toscani avoids advertisements featuring products (in the case of Benneton, clothing and accessories for young people) or using associative juxtaposition clichés (such as using female models in provocative positions associated with products). On 
the contrary, the Benetton campaigns outline an attitude and denote an artistic preoccupation whose depth is defined on two levels:

1) it relates to the advertising market, projecting itself as an alternative image, unconventional, original, ensuring the functionality and visibility of the advertisement;

2) builds an ideological attitude that is associated in consumer behaviour with the quality of Benetton products, a solution whose functionality may seem paradoxical, especially from the perspective of completely excluding the display of (the image of the) products in billboards (Barthes, 1977).

In terms of advertising marketing, Toscani builds and cultivates the brand awareness, yet extends this formula to everything that means advertising for the Italian company, avoiding any form of direct product promotion, visual or verbal representation: the power of the brand becomes an expressive priority over the products represented.

From a visual syntactic point of view, the tensions reside only from the formal association of the subject with the Benetton logo box, so from the re-signification of a concept in the conditions of the advertising expression. This mutation of meaning is, in fact, apparent, marking a level of normality of perceptions that society, in its pursuit of consumerism, entertainment and industrialization, no longer associates with normal (non-alienated) behaviour (Soreanu, From Media to Mediums of Expression. Visual Art Communication and Meaning, 2020).

Oliviero Toscani's originality lies in the nature of his advertising approach, more precisely of the subjects and their relationship with the advertising approach. Defying conventions, overcoming social barriers and taboos, the artist constructs work, whose value transcends the advertising dimension of the construct, to the artistic one. At the level of the semiotic mechanism, Toscani fulfils one of the fundamental premises of the definition of advertising as visual art: the distinction between the signalling and the symbolizing functions of the expressive construct. Through symbolic evocation, art manages to access a semantic field of a specific expressive consistency (Soreanu, 2018). In advertising, this landmark of symbolism is added to the signalling function that has the persuasive ability to achieve, through precision and success, a very clear semantic register (hence the space-time identification that defines advertising).

Carried out under the restrictive auspices of the market economy and having to respond to marketing reasons, advertising is seldom permissive for the artistic contribution of creators. Advertising has trends, involves recipes, clichés and solutions whose operation ensures concrete results, translated into positive 
turnovers. From this point of view, Toscani's authorial approach had the chance of an optimal configuration, materialized by ensuring a potential brand in development (United Colors of Benetton, the brand under which Benetton promoted their products in 2000s), the artistic genius of the artist (Oliviero Toscani), a saturated advertising market bored with clichés (both European and international), but especially by the permissive and open attitude of the owner of the Italian company (Luciano Benetton) who gave a "carte blanche" to Oliviero Toscani, fully confident in his potential to promote the company's image (Del Drago, 2013).

At a final glance, all of the advertising campaigns of the Italian company Benetton, designed and coordinated between 1982 and 2000 by Oliviero Toscani, manage to fulfil this desire of advertising (as an integral part of the visual arts family), to complete the expressive offer of art based on the recovery of traditional professional standards. Oliviero Toscani's works return to publicity the role of factor of public awareness and social reflection; addressing controversial topics in unique ways, despite social behavioural rules and canons, his advertisements demonstrate that quality advertising can be a construction with a remarkable semantic magnitude which is specific, in general, to art [3] (German, 2018).

\section{Two decades of advertising campaigns for Benetton}

Among the first controversial campaigns of the Benetton company [4], created by Oliviero Toscani, are the images whose theme evokes the notions of racial equality, images that caused strong reactions of the black community in the United States: two handcuffed male hands, one white and one black (Fig. 1), and that of a black woman breastfeeding a white infant (Fig. 2). Acute racial criticism stems from the reaction of the American public, whose interpretation offered new meanings to the construction of advertising: the reference to America's enslaved past, the latent memories of black nurses who used to breastfeed children of white 'masters', deliberately maintained social uncertainty, ensured the advertising success of the campaign, probably one of the most memorable and recognizable in the history of Benetton campaigns. In the case of the first image, the two handcuffed hands clearly raise the issue of class equality (similar clothing, jackets and jeans), the balance of power (who handcuffed whom, who is the policeman, who is the victim), racial appearance (a white hand, a black one). Toscani, the author of the images, creates an intentional confusion, asking the public to formulate, cultivate and express their own opinion.

Benetton's subsequent campaigns continued in 1990 and 1991 with other series of symbolic posters promoting the concept of equality in diversity (with award- 
winning images in Austria, France, the United Kingdom, the Netherlands and the United States), focusing on the same issue of racial discrimination. 'Hands' and 'Children on the pot' use photographs of children (Fig. 3-4), Toscani moving the meaning of advertising construction to the area of childhood and behaviour learned or assumed from the family: a hand of a child of colour superimposed on the image of a white hand, adult, a visually relational tensed composition (invoking the concepts of protection, parenting, possible gesture of refusal) or the image with the two children, one black and one white, sitting on the pots, in a moment of childlike intimacy. The 1991 version, 'Angel and Devil' connotes, through the image of embraced children, the idea of assigning social labels against the background of racial segregation, as a predestination of today's society (Fig. 5). The 1990 "Blanket" also raises the issue of considering homosexual relations and the relationship between its members amid racial disputes: in the same blanket, equally a symbol of refugees or family warmth, are a white woman, an Asian child, and another woman of colour (Fig. 6).

The 90s' campaigns created unprecedented controversy, following the company's attempt to use real-world images, images of social-universal relevance, in order to break the barrier of indifference and stimulate the revival of public consciousness. Racial issues, family issues, sex and (in the case of 'Graveyard' from 1991 - Fig. 7) war, become favourite topics of Benetton advertising, through their potential to be anchored in reality. Toscani builds his works with an agile sense of reality and the weight in daily life of social landmarks whose perception is deeply alienated. Calling the same racial theme or social pseudo-customs conditioned by the consumer society, Benetton uses the image of a new-born not yet detached from the umbilical cord, as a metaphor for the cruel and brutal connection to real life (Fig. 8) or the (almost) ridiculous sequence of wooden figurines, a satire on the uniformitarian social conformity of races, holder of contemporary strings and socioeconomic levers (Fig. 9).

In advertising, the lector interpretation is crucial in producing meaning, and the meanings of an advertisement depend on the cultural context in which they are received, fulfilling (paradoxically) the advertising stake regardless of its acceptance or rejection. An example is 1991's 'Tongues', depicting three children (one black, one white and one Asian) with tongues out, an eloquent example of how a universal theme confronts cultural barriers: the image was considered "pornographic" and prohibited in some Arab states, where the display (and, therefore, reproduction) of an internal organ or body parts is prohibited. Controversial reactions also sparked "Kiss", an image of a white man kissing a woman of colour on the cheek, defying 
racial and gender distinctions that, in the early 1990s, still persisted in some European countries and certainly in the United States (Fig. 10).

"Eyes" is the work that marked the establishment of the centre of artistic studies and research called 'Factory', founded by Oliviero Toscani and funded by Benetton - a frame with a coloured figure whose eyes, different colours, symbolize openness to diversity and spirit visionary of that centre (Fig. 11). One year later, Toscani resumes the theme of racial equality with a unique work that has caused a stir on billboards around the world, called 'Hearts': three freshly gutted, presumably human hearts, over which are labelled White, Black and Yellow (Fig. 12). 'Hearts' is a metaphor for a return to the very essence of human life and spirit, and the work symbolizes inter-racial equality in a formula that rewrites the image standards of contemporary advertising.

If in 1991, Toscani included in the repertoire of advertising images the photograph of a cemetery from the First World War in France, with symmetrical rows of crosses, reminding that no one wins in war and that beyond uniforms, races and religions, death is the only victory (figure 7), in February 1992, Benetton introduces a new controversial campaign: it involves the use of real images, made by photojournalists and already used in the press, appropriated images from the news, reports or investigations. The topics chosen are in line with Benetton's philosophy and socio-political concerns: illustrating obscure diseases and illnesses, overcoming violence and social intimidation, forced emigration, natural disasters, etc. The moment is particularly important in international advertising, because it marked a total break with the advertising conformity that involved the creation of advertisements in which to appear or be suggested the product (as an advertising referent), with the metonymic use of signs and polysemous constructions that to support its qualities. Toscani had already introduced a visual formula in which the advertising construction completely ignored the reference product, but now it does so through images whose existence is avoided or even denied by the world of consumerism and entertainment. War, illegal emigration, famine, brutality, mortality, execution, the death penalty, AIDS, are becoming topics of publicity. Toscani clearly refers to the capitalist society whose symptoms are visually translated in the construction of advertising. In his works, reality becomes part of advertising, as a form of social therapy through visual art. Appropriating his press images and resignifying them in advertising images, Oliviero Toscani transfers to Benetton's campaigns the worrying tragic dimension of a reality that transcends the limitations of the perception of a society alienated from consumerism, crushed by economic 
differences, sabotaged by capitalist policies and political and cultural colonialism (Lyman, 2001).

In 'Soldier with the Bone', the image of a black soldier, photographed from behind with an automatic pistol hanging from his shoulder, holding a human femur in his hands, is a terrible vision of the social anxieties of the ' 90 s related to colonialism, racism and sub-culture in conflict zones in Africa, a denunciation of the primary condition of violence and the scale of armed conflict around the world (Fig. 13). Also in 1992, Toscani made other image commercials evoking an episode in the desperate attempt of several thousand Albanians trying to embark on a ship, a besieged boat in search of utopian freedom, a form of economic dignity, oppressed in their own country and without the chance to be received in another state [5]. The work 'Container' presents a similar situation, uncomfortable for Western public opinion, an image that captures dozens of black people huddled in a freight car, in an improbable amalgam unfamiliar to those deprived of the basic rights and comfort of existence especially in Eastern Europe (Fig. 14).

On the same note, the photograph (this time taken by the Toscani himself, two years later) of the blood-stained uniform of soldier Marinko Gagro, a victim of the war in the former Yugoslavia, is resigned as a symbol of peace in the poster 'Soldier', highlighting the brutality of the war that the media presents as a spectacle (Fig. 15). 'Barbed wire' from 1995 is a composition that illustrates different types of barbed wire from South Africa, former Yugoslavia, Mexico, Lebanon, Japan, Israel, Hungary, Brazil, Ireland and Germany, wire with which they are fenced both refugee camps or state borders, as well as private property in developed societies (Fig. 16). Both posters denote the perception, at the social level, of the neighbouring and immediate conflict reality and the awareness of the issue of borders and inter-ethnic barriers, against the background of the crisis of segregation of former communist states or against the sharpening of social class differences in capitalism. The critique is obvious, functioning both as a distinct signalling and as a metonymic symbolization of restrictive regimes and political, social or cultural barriers.

The visual construction of these ads confirms the position and philosophy of Benetton, which tries to create a certain emulation, a reconsideration of the social state, of reviving the public interest in the real problems of everyday life. From an advertising point of view, the works work by associating the target audience with the respective ideological context and its enrolment in the virtual community of supporters.

Some of Toscani's most controversial works relate to AIDS victims. The 1992 AIDS - David Kirby commercial, based on a photo appropriated from a documentary 
series by Therese Frare (Time.com, 1990), depicts the grieving family of a dying man, in which the shock of receiving the scene precedes any other type of aesthetic reading (Fig. 17). The dying is disfigured, the family is destroyed, the scene is of a realism that could be suspected of theatricality, if it were not true. The image plays a feast to the viewer, the cultural references being extremely strong: the work has the emotional charge of a Renaissance Pieta, the consumerist critique of Duane Hanson, and the tragedy of a cinematic setting [6]. Paradoxically, Oliviero Toscani talks about death in an advertisement bearing the Benetton brand, and the author's intention is to raise the level of acceptance and awareness of the aspects of life and death of those around us. The same subject is touched on in 'AIDS faces', where Oliviero Toscani composes a composition of smiling portraits of over a thousand young people around the world (forming the word AIDS), as a suggestion of the presence of the disease that has become a metaphor for the anxieties of the 20th century (Fig. 18). A more recent series of works resumes the theme of AIDS patients (in 1993), depicting marked/stamped body parts of a person, stigmatized with the words 'HIV Positive', a visual illustration of social discrimination of those diagnosed with the disease. Drawing attention to the social death of AIDS patients, caused by public isolation, Toscani's posters reveal the social fears and anxieties that characterize contemporary society and its predisposition to avoid or marginalize the problems they face (Fig. 19).

The subject of erotic and sex (and its representations, with a special expressive potential), was not avoided by the artist, especially since it is one of the most generous social taboos, defining types of projected identity constructions, gender behaviour or customs and restrictions. The few campaigns that critically address this issue have been running for several years, from the Condoms and Olympic Games of 1991-92 (practically illustrations of the universality of the concept of unity in diversity, specific to the incipient Benetton campaigns), to "Horses" from 1996, a very explicit - but unique - illustration of 'wild sex' (Fig. 20). Toscani also juggles social prohibitions in his notorious 1991 work "Priest and Nun", a poster depicting two kissing characters (a priest and a nun, Fig. 21), a direct critique of Catholic Church morals and contemporary social conventions (Soreanu, The Sacred In Contemporary Advertising, 2016).

Addressing reflective issues on major issues of contemporary society, Benetton's works also include images that illustrate the effects of pollution on the environment: the pseudo-aesthetics of some oil-floating leaves photographed by Toscani, or the use of Steve McCurry's image of a bird trapped in the layer of oil residues, doomed to death. In 1996 and 1997, in collaboration with the FAO (Food 
and Agriculture Organization of the United Nations), Benetton created the official image of the World Food Summit (Rome, 1996). Oliviero Toscani uses a simple composition, the photograph of a wooden spoon on a white background, illustrating man's relationship with primary food resources (Fig. 22). Simple and direct, advertising is another form of advertising that comes as a confirmation of the quality of Benetton's advertising campaigns, concerned with highlighting social issues of global importance such as peace, the fight against racism and respect for racial and ethnic diversity [7]. In 1997, Benetton proposed another image, a photograph of a black person's hand holding a few grains of rice in his open palm. The uncertainty of the relationship between the hand gesture (which either demands or offers) and the racial and economic-exploitative dimension (black hand and white rice) of the composition, invites reflection on Benetton's messages, unique and completely different from the 'standard' images of the advertising industry (Fig. 23). Next year, in conjunction with the 50th anniversary of the United Nations Declaration of Human Rights, Benetton and Oliviero Toscani launch two images that seek to remind international public opinion of some of the fundamental human rights and highlight that protecting these rights is the first responsibility of the UN member states. The images show the figures of young people from all over the world, with the symbolic power of Benetton campaigns and were presented simultaneously in the media around the world, on billboards, on buses or in public transport stations (Fig. 24).

The works from the controversial series "We, on Death Row", are part of the same tradition of approaching the borderline, taboo topics of society. Toscani uses portraits of death row inmates in American prisons, accompanied by the text "Sentenced to Death", in a setting that seeks to resurrect a level of social consciousness and take a stand on the issue of capital punishment. Oliviero Toscani spent few years photographing convicts in American prisons for the 2000 advertising campaign. The death penalty is a reflective theme that creates an emotional response that the artist relies on in his works: Toscani's stated intention was to draw attention to the radical nature of capital punishment and its inhumanity, in a form that provokes the public conscience. With their faces turned to the camera, the subjects of the campaign interrogate the viewer, accusing him not only of the injustice of the American judicial system, but also of the lack of reaction, of accepting the social convenience, of the injustice of these social purification mechanisms.

In the United States, there has been a significant reaction from the public, from regular buyers of Benetton products, to organizations of victims of death row inmates, who have organized demonstrations and filed petitions against Benetton, 
accusing it of exposing the figures of the convicts and of obtaining profit from the sufferings of their victims. Beyond the vehemence of public opinion [8], the decisive factor in the decision to give up that campaign came with the decision of the commercial giant Sears in the United States to give up marketing Benetton products. Toscani has repeatedly stated his point of view, mentioning his impartiality and objective quality as an advertising creator [9].

Thus, the works of the Benetton campaigns from 1982 to 2000 manage to arouse the public's interest by appealing to topics such as eroticism and sexual taboos, racism, psychosis caused by AIDS, anorexia, or themes such as ecology or armed inter-ethnic conflicts. Toscani's favourite themes are the liminal topics of contemporary society, which the artist's agile sense of observation identifies and materializes. The active interpretation of the public, recommends them as cultural idioms whose universality is disputed at the level of questioning the elementary conditions of humanity. In the case of the advertising campaign where he used photos of the death row inmates in American prisons, Benetton made an extremely risky bet with the consumer market, in which it assumed not only the inherent risks of any advertising campaign, but also those of taking a position and of the moral load of the meanings that the works can acquire in different reception environments [10].

\section{A critical approach: reading Benetton advertisements}

From a reading perspective, as symptoms of today's social trends, political fears and crisis, and also artistic and cultural manifestations, Oliviero Toscani's works for Benetton are subject to interpretation from several directions of the advertising approach:

a) The international, globalized addressability: by their very nature, these are works addressed to a world-wide target public. However, the reception and interpretation of advertisements (hence their meaning) is done according to the specificity of each culture. Toscani's ads resonated among the most diverse in the world, ranging from thunderous success in European states, to complete bans and even street demonstrations against the Benetton campaign and products in others (such as US or Middle Asia Islamic states);

b) The dissemination through contemporary media; more and more, this eliminates the time and space differences, as these are campaigns presented simultaneously all over the world, from USA to Japan;

c) Fully addressing a capitalist society, against the background of globalization, convergence and world economic synergy (Sturken \& Cartwright, 2001). From totalitarian, expansionist American capitalism to the emerging forms of pseudo- 
capitalism in Eastern Europe, Toscani's advertising works manage to arouse interest, raise questions, and give rise to controversy.

Toscani's images are promoting equality in rights, humanity, and tolerance, addressing the society of the 1990s going through a multitude of crisis: the post-racial crisis, acceptance and awareness of the AIDS threat, post-communist crisis, and also national-ethnic crisis of the division of ex-communist federal states in Eastern Europe. With a deeply humanistic character associated with an interrogative dimension, Benetton advertisements' message is addressed to a tensed humanity (and toward its response to it), through visual constructions and artistic strategies that show deep concern and involvement in identifying, accepting and solving the real problems of today's society.

\section{Discussion}

As advertising becomes increasingly central to the cultural understanding of people's everyday lives, it is important how we perceive the new mediums' influence over the way we live. More important, to realize how the shifts in crafting, disseminating, and digesting these important assets of cultural visuality - namely the advertising products, the ads - are literally shaping the world as we see it. Toscani's advertising marked a break point, precisely because it used artistic strategies, uncommon to advertising, to reveal an attitude rather oriented toward individual perception and social integrity, rather to the consumerist dimension of living. It also mixes mediums and resources coming from the objectivity of a journalistic direction, with a resolve of the visual strategy based on artistic postmodern approaches. Moreover, it creates a direction of discussion which embodies the taboo topics and the thematic widely avoided by the commercial visual industry, with an ethical questioning of daily life values, or various social and political aspects and decisions. The question is if, on one hand, advertising is the ethical tool for nowadays cultural studies revealing social and political shifts, and - on the other hand - how much of Toscani's intervention in the public space of visual consciousness, through art campaigns, corporate advertising, brand awareness, and product promotion, became landmarks in the way we see advertising today, years after his collaboration with Benetton.

\section{Conclusion}

This study established that while controversial topics are generally suppressed in modern society and become taboo topics, Oliviero Toscani's practice is clearly oriented towards understanding and overcoming these subjects, with a deep 
humanistic intent in his work and a creative direction that expressively enriches Benetton's campaigns, shifting the emphasis from the company's products (nonexistent as an image) to building an identity and an awareness with which the Benetton customer is invited to identify. The strong attitude of awareness of public perception is what defines the advertising process in the acceptation of Oliviero Toscani, who almost reverses the transfer of ideological identity between the artistic approach and the advertising product: his works are what's promoted through advertising campaigns, not the other way around. While moving away from clichés and stereotypes in advertising, the logic is also supported by the exceptional addressability of the works in the commercial advertising repertoire, and by the openminded dedicated target public of Benetton.

The images he used for Benetton, as advertising products, relied on the discrepancy between the nature of the promoted product and the ideological context that "clothes" the image of the manufacturing company. Presented only with the green logo 'United Colours of Benetton', discreetly arranged in the composition and consisting exclusively of printed materials (street posters, billboards, and advertisements for magazines and specialty stores), the ads created by Oliviero Toscani depicted controversial topics of international society, whose major tension lies precisely in their very association with the advertising product.

Future research into advertising should focus on establishing a clearer picture of how ads, commercials, and marketing campaigns (as advertising materials/phenomena) can actually become symptoms of artistic behaviour in today's visual culture. Furthermore, while this study analysed only a specific case studies corpus based on Toscani's first decades of collaboration with Benetton, more observational studies are required to establish a deeper insight into different patterns of usage artistic mediums such as photography, or painting, reflected in both European and Benetton's advertising, while correlating thematic and topics, with the subjects of representations meaning.

\section{References:}

Barthes, R. (1977). The Photographic Message. New York: Hill \& Wang. Benetton Group. (2021, April 13). Campagne Storiche - Immagini. Retrieved March 01, 2021, from http://www.benettongroup.com/it/mediapress/immagini/comunicazione-istituzionale/campagne-storiche/ 
Benetton Group. (2021, April 13). Campagne Storiche - Immagini. Retrieved March 01, 2021, from http://www.benettongroup.com/it/mediapress/immagini/comunicazione-istituzionale/campagne-storiche/

Benetton Group (2021). Press Releases and Statements. Retrieved March 06, 2021, from http://www.benettongroup.com/media-press/press-releases-and-statements/ Benneton Group (2000, January 07). Looking at death in the Face. Retrieved April 19, 2021, from Press Releases and Statements http://www.benettongroup.com/media-press/press-releases-andstatements/looking-at-death-in-the-face/

Berger, W. (2001). Advertising Today. New York: Phaidon Press.

Day, J. (2001, June 18). Benetton apologises over 'death row' ads. Retrieved April 19, 2021, from

https://www.theguardian.com/media/2001/jun/18/advertising.marketingan dpr

Del Drago, E. (2013, February 26). Interview Oliviero Toscani: Back to the future (06). Retrieved February 28, 2021, from https://www.klatmagazine.com/en/photography-en/oliviero-toscaniinterview-back-to-the-future-06/37739

Duane Hanson (American, 1925-1996). (n.d.). Retrieved April 19, 2021, from http://www.artnet.com/artists/duane-hanson/

FABRICA (2021, February 01). Fabrica is a communication research center. Retrieved February 28, 2020, from http://www.fabrica.it/about/

German, L. (2018). The relation between "seeing" and "being seen": a diachronic perspective on photographic view. Comunicarea interpersonală. Arta şi educația ca mijloace de comunicare, 187-193. Iaşi: Ars Longa.

Immagini (2018, June 21). Media \& Press. Benetton Group. Retrieved February 03, 2021, from http://www.benettongroup.com/it/mediapress/immagini/comunicazione-istituzionale/campagne-storiche/

Lyman, E. J. (2001, August). The True Colors of Oliviero Toscani. Retrieved February 28, 2021, from http://www.ericjlyman.com/adageglobal.html

Photos of Albanian Refugees Arriving in Bari, Italy, 1991. (2017, January 09). Retrieved April 19, 2021, from https://historydaily.org/albanian-refugees-arriving-inbari-italy

Povoledo, E. (2020, February 6). New York Times. Retrieved March 6, 2021, from https://www.nytimes.com/2020/02/06/world/europe/benetton-olivierotoscani.html? 
Soreanu, C. (2016). The Sacred In Contemporary Advertising. (C.-L. Ioniță, P. Ioniță, \& B. Grigoriu, Eds.) ANASTASIS - Research in Medieval Culture and Art, 3(1), 149-158.

Soreanu, C. (2018). Artă şi publicitate. Medii de expresie in publicitatea contemporană. Iaşi: Artes.

Soreanu, C. (2020, November). From Media to Mediums of Expression. Visual Art Communication and Meaning. (C.-L. Ioniță, A.-I. Stoleriu, \& A. Stoleriu, Eds.) ANASTASIS - Research in Medieval Culture and Art, 7(2), 261-276.

Sturken, M., Cartwright, L. (2001). Practices of looking, an introduction to visual culture. NY: Oxford University Press.

Taraşi, M. (2006). Sens şi expresie in arta contemporană. Iaşi: Artes.

Time.com (1990). The Face of AIDS - Therese Frare. Retrieved February 28, 2021, from http://100photos.time.com/photos/therese-frare-face-aids

Tomkins, R. (2010, August 19). Oliviero Toscani: 'There are no shocking pictures, only shocking reality'. Retrieved March 06, 2021, from http://edition.cnn.com/2010/WORLD/europe/08/13/oliviero.toscani/inde x.html

Toscani, O. (2021). Oliviero Toscani - Biography. Retrieved February 28, 2021, from http://olivierotoscani.com/biografia en.html

\section{Notes:}

[1] In parallel with his work at Benetton, Oliviero Toscani conceived in 1990 a global publication-store called Colors, and in 1994 he founded Fabrica, an international center for research in art and communication, based in Treviso, Italy. (FABRICA, 2021)

[2] His works have been exhibited at the Venice Art Biennale, San Paolo, the Milan Triennials, Lausanne, Mexico City, Helsinki, Rome, and in countless galleries and museums around the world. Winner of four 'Golden Lions' at the Cannes Film Festival, the UNESCO “Grand Prize”, two 'Grand Prix d'Affichage', etc. (Toscani, 2021)

[3] In his interview under 'Pushing the limits' chapter of Phaidon's 'Advertising Today' from 2001, Oliviero Toscani argues that the advertising “... could be an incredible art form. When you look back into history and look at Renaissance painting, that was like advertising painting in the church. The painters were called in to express a religious idea, which was like a product - so the painting was there to promote a power, a king, a religion. But those Michelangelos and 
Leonardos were able to transcend all of that to become art. And we should do the same." (Berger, 2001)

[4] We mainly focus our case studies on Toscani's work made for Benetton from 1982 to 2000, when he ended his activity as a result of the consequnces of 'Death Row' posters campaing in USA (Benetton Group, 2021). However, he reconnected with Benneton in 2017, just to end it again in 2020. (Benetton Group, 2021)

[5] The episode took place in Bari, Italy, on August 18, 1991. (Photos of Albanian Refugees Arriving in Bari, Italy, 1991, 2017)

[6] Duane Hanson (1925-1996) was an American artist whose works were part of Pop-Art and Hyperrealism, with critical accents on consumer society and alienated forms of behavior, as seen in 'Supermarket Lady', from 1969. (Duane Hanson (American, 1925-1996))

[7] Benetton has been involved as an active partner, designing and implementing initiatives of global importance such as the Clothing Redistribution Project, the Sarajevo - Heart of Europe project and AIDS prevention campaigns in South Africa, India and Brazil, participating in projects organized by the Red Cross, SOS Racism or the World Peace Organization. (Benetton Group, 2021).

[8] The reaction of retail chains such as Sears and Roebucke ${ }^{2} \circ$ was to boycott and refuse to sell Benetton products. (Day, 2001)

[9] „I'm not a judge. I'm not a social worker. This campaign is not about victims. It is about the death penalty. The death penalty is unreligious. The 10 Commandments say 'Thou shalt not kill.' It is against the law." Oliviero Toscani, Press Release, 2001. (Tomkins, 2010)

[10] "Bitterly attacked by some and internationally acclaimed by others, Benetton's campaigns have managed to tear down the wall of indifference contributing at raising the awareness of universal problems among world's citizens." (Benneton Group, 2000)

[11] All illustrations are available for editorial use (not for commercial purposes) on Historical Campaigns page from Benetton's company website (Immagini, 2018). 


\section{Appendix [11]}

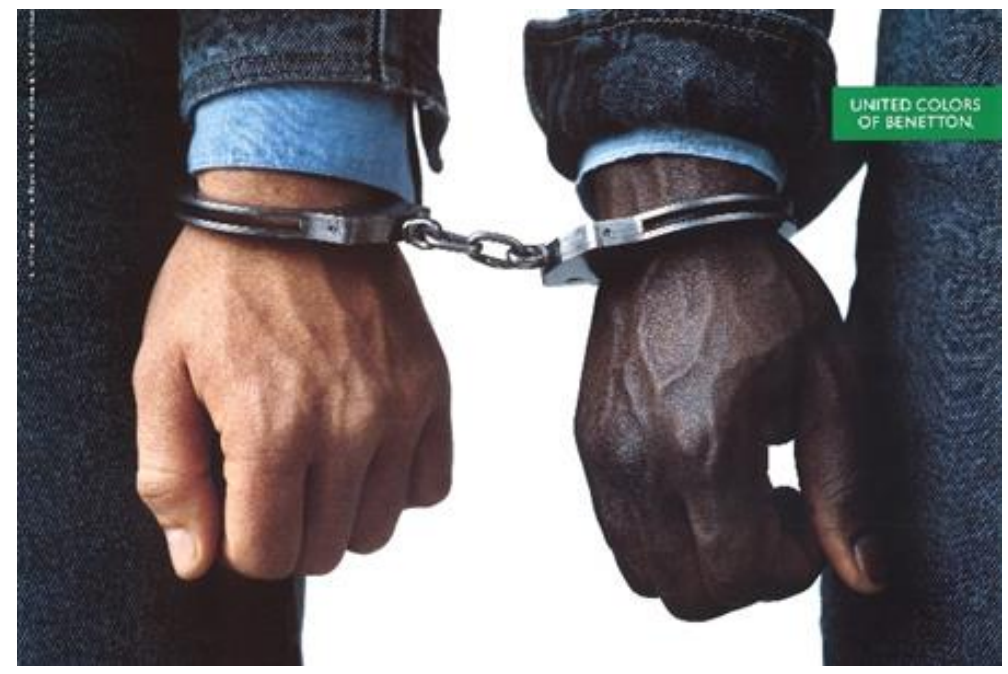

Figure 1. A/I 1989: 'Manette' (Handcuffs). Photo: Oliviero Toscani. (C) Benetton Group

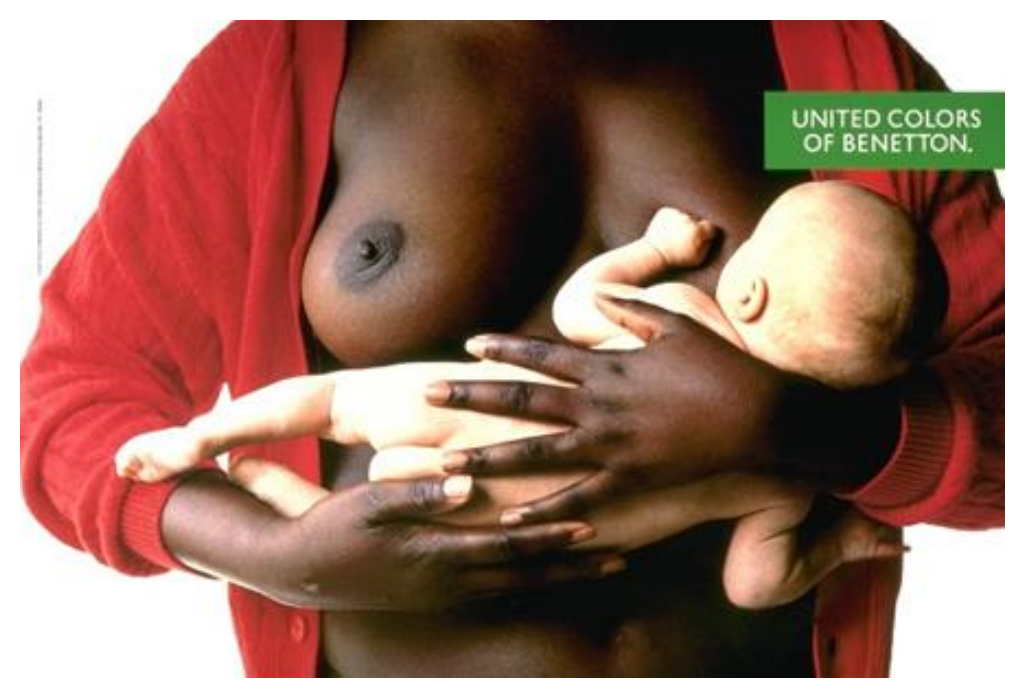

Figure 2. A/I 1989, 'Donna che allatta' (Nursing woman). Photo: Oliviero Toscani. (C) Benetton Group 


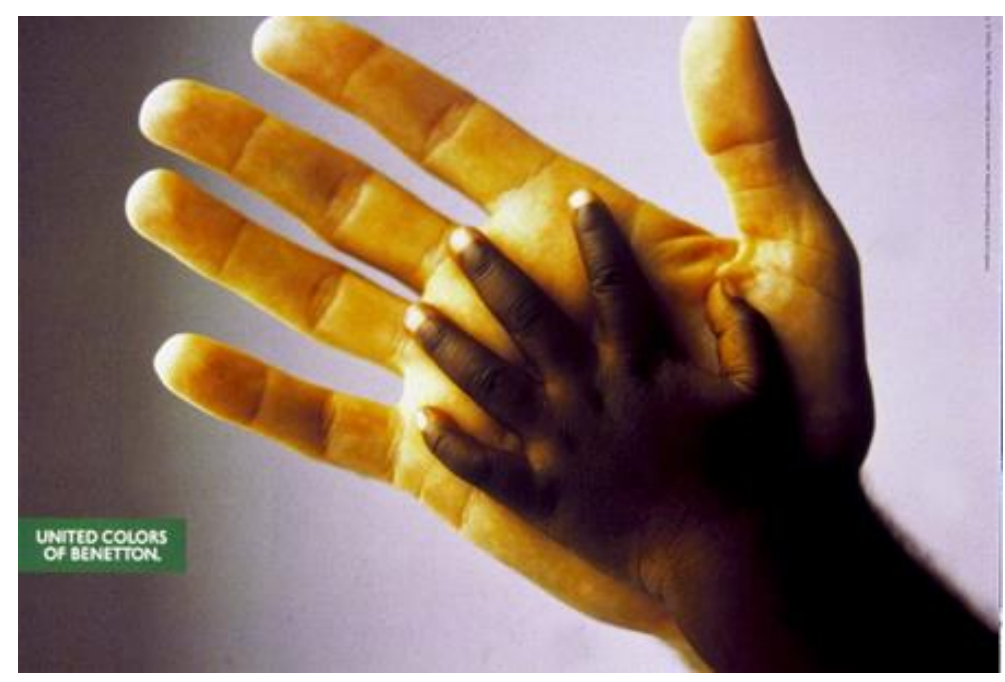

Figure 3. P/E 1990, 'Mano bianca e nera' (Black and white hand). Photo: Oliviero Toscani. (C) Benetton Group

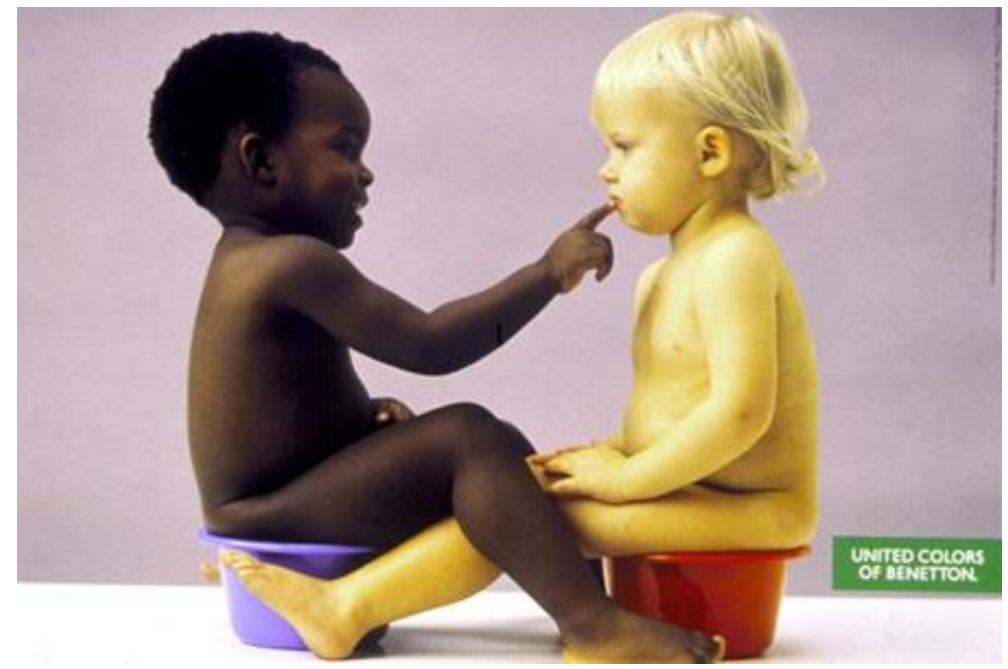

Figure 4. P/E 1990, 'Bambini sul vasino' (Children on the potty). Photo: Oliviero Toscani. (C) Benetton Group 


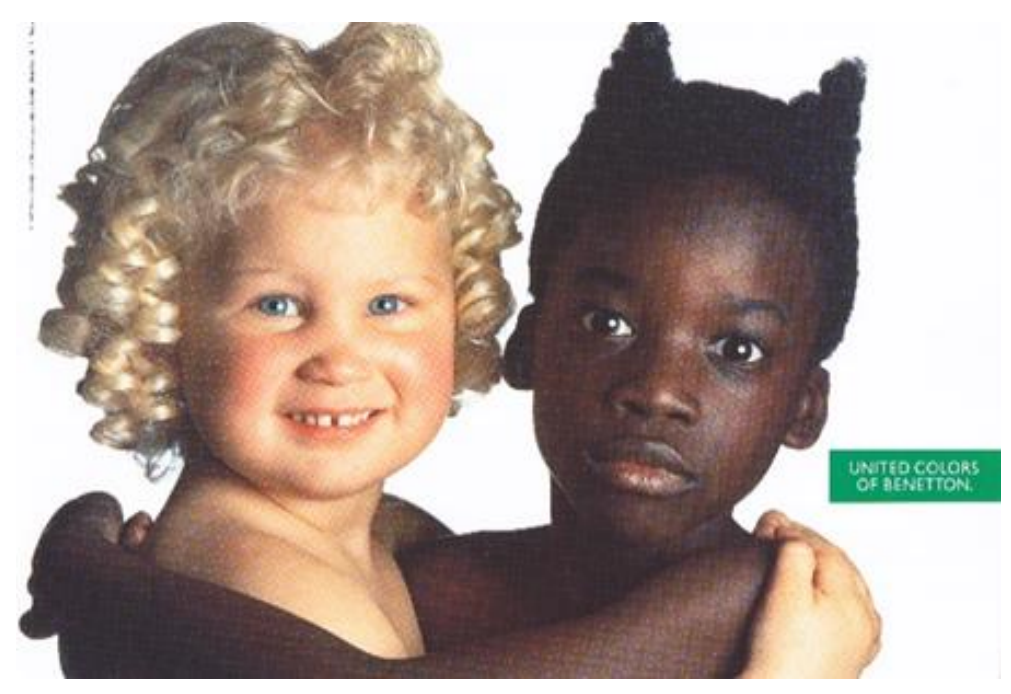

Figure 5. A/I 1991, 'Angelo e diavolo' (Angel and devil). Photo: Oliviero Toscani. (C) Benetton Group

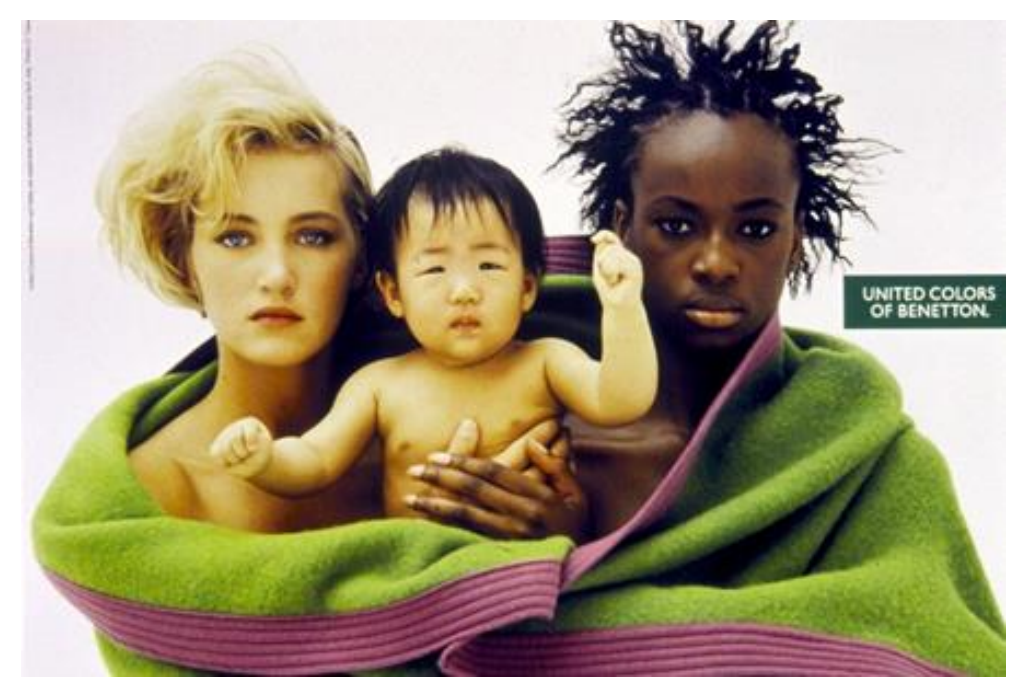

Figure 6. A/I 1990, 'Coperta' (Blanket). Photo: Oliviero Toscani. (C) Benetton Group 


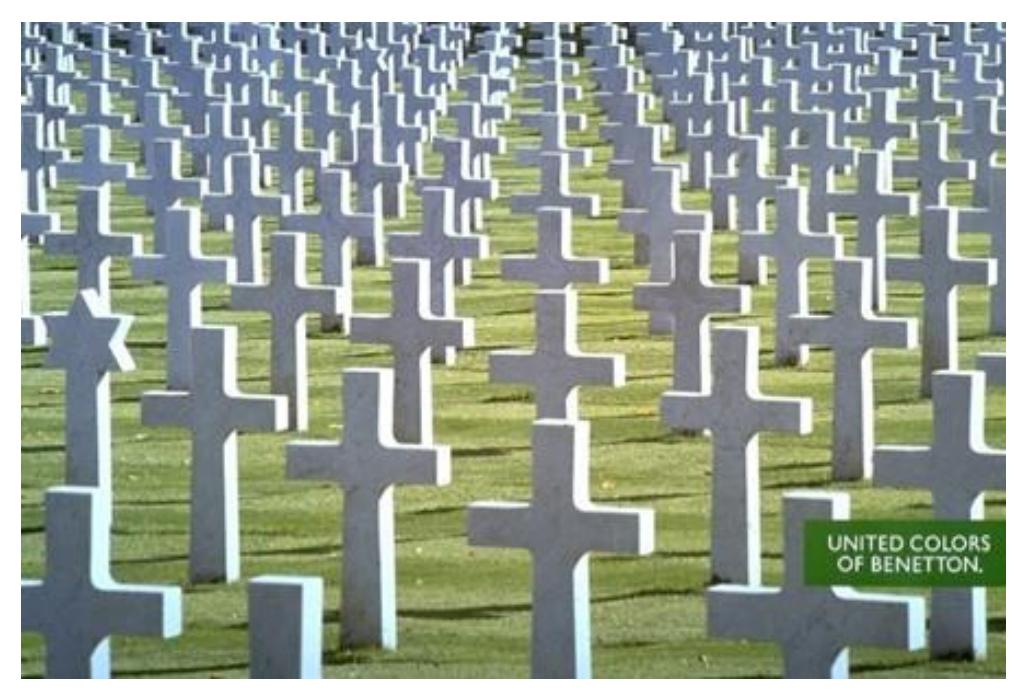

Figure 7. P/E 1991, 'Cimitero di guerra' (War cemetery). Photo: Oliviero Toscani. (C) Benetton Group

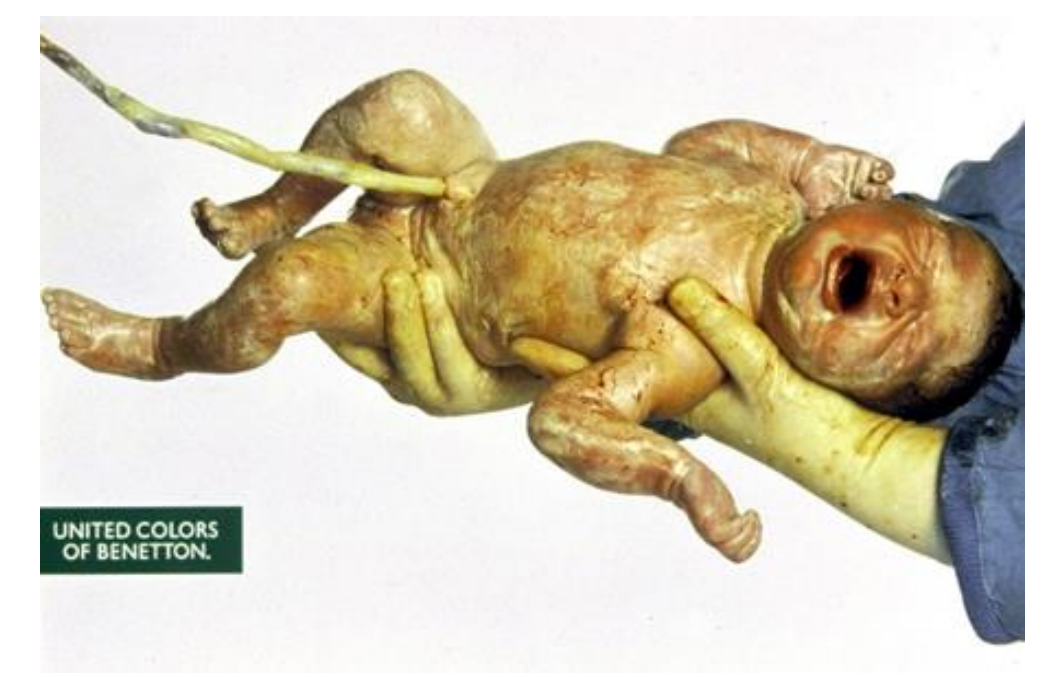

Figure 8. A/I 1991, 'Neonata' (Newborn). Photo: Oliviero Toscani. (C) Benetton Group 


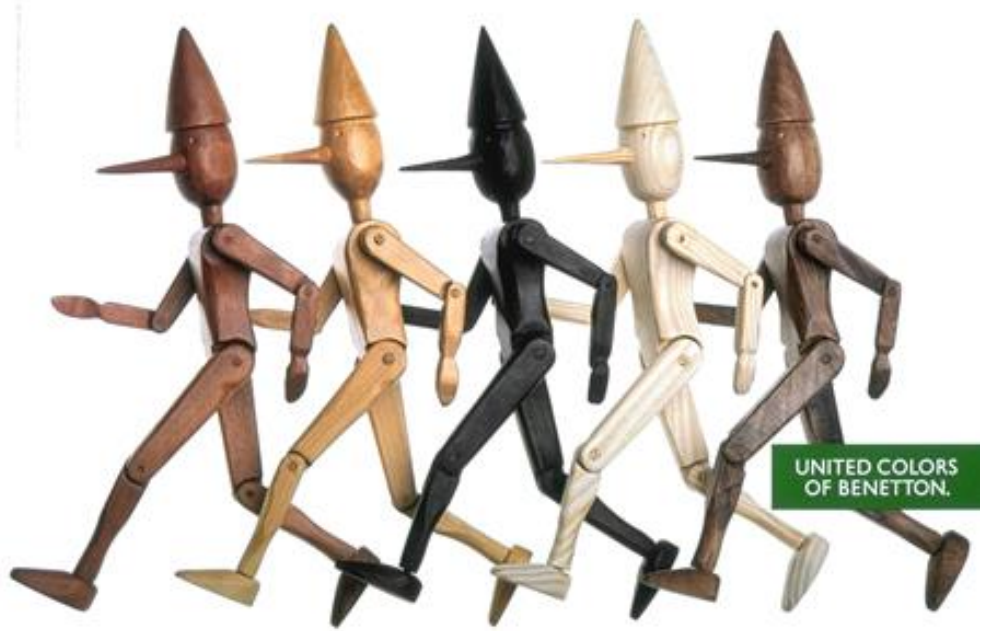

Figure 9. P/E 1991, 'Pinocchi' (Pinocchios). Photo: Oliviero Toscani. (C) Benetton Group

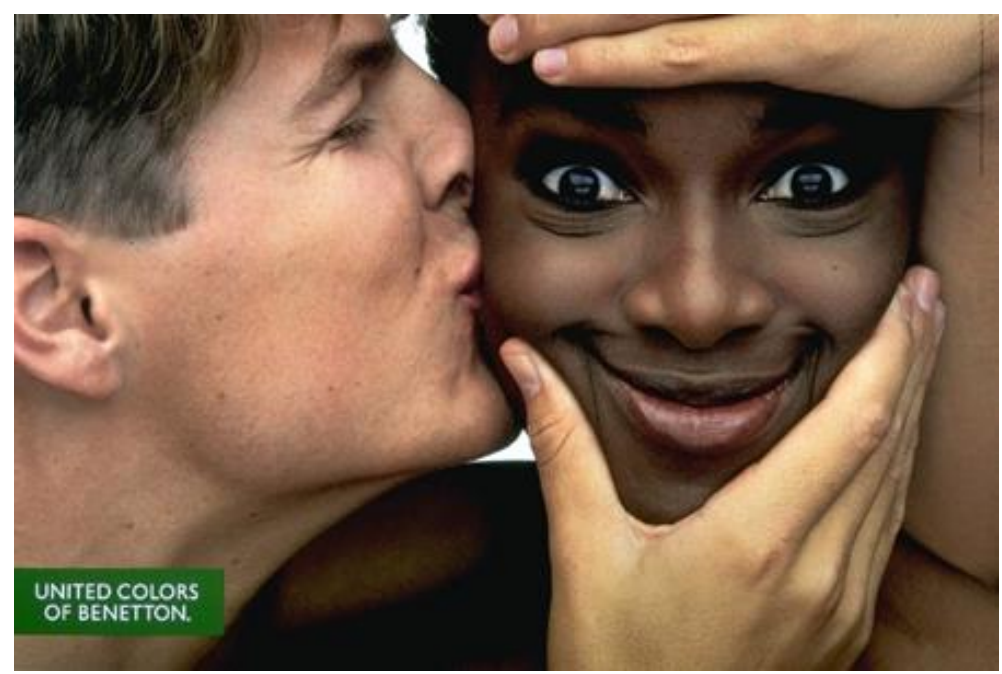

Figure 10. P/E 1991, 'Bacio' (Kiss). Photo: Oliviero Toscani. (C) Benetton Group 


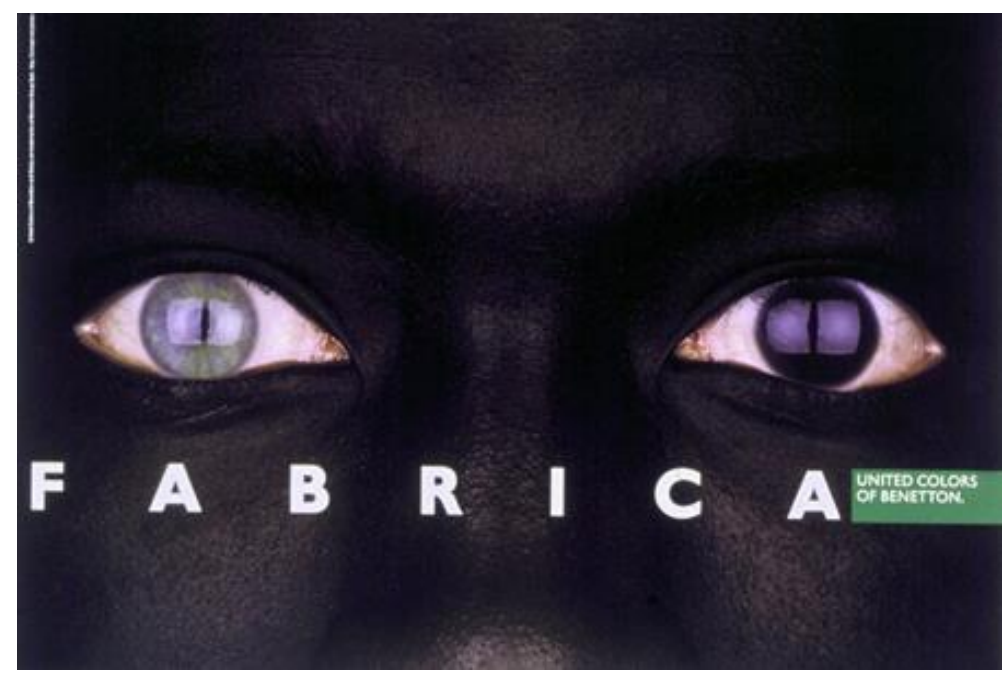

Figure 11. A/I 1995, 'Occhi - FABRICA' (Eyes FABRICA). Photo: Oliviero Toscani. (C) Benetton Group

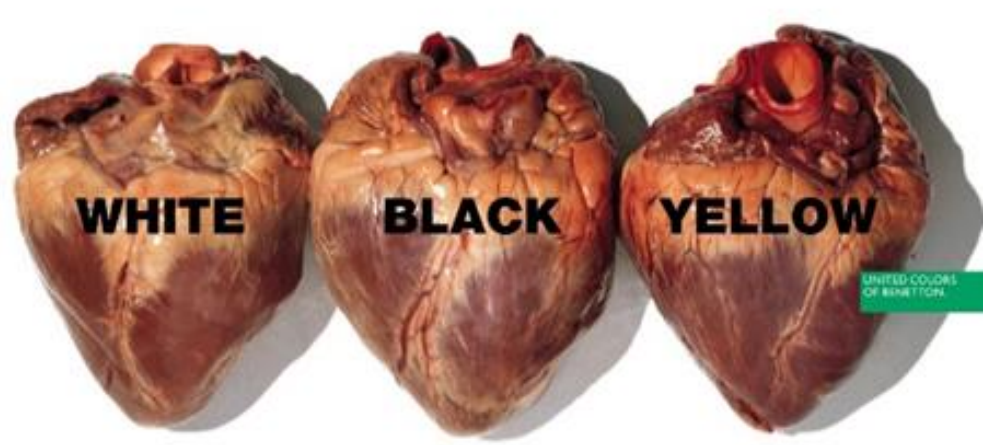

Figure 12. P/E 1996, 'Cuori' (Hearts). Photo: Oliviero Toscani. C Benetton Group 


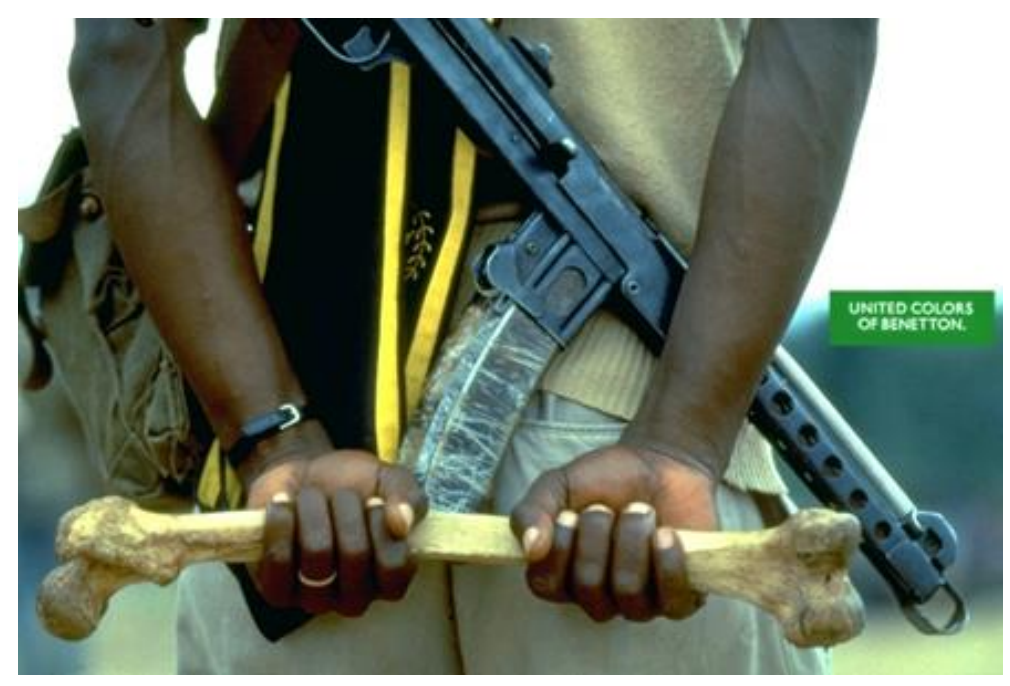

Figure 13. P/E 1992, 'Soldato con osso' (Soldier with bone). Concept: Oliviero Toscani. Photo: Patrick Robert/Sygma. (C) Benetton Group

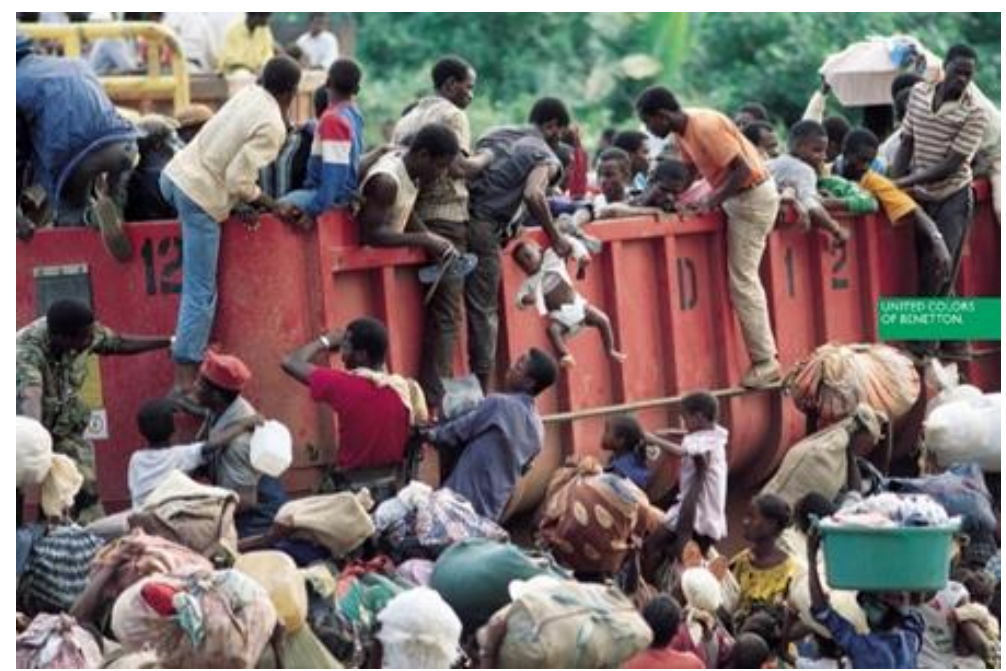

Figure 14. P/E 1992, 'Container'. Concept: Oliviero Toscani. Photo: Patrick Robert/Sygma. (C) Benetton Group 


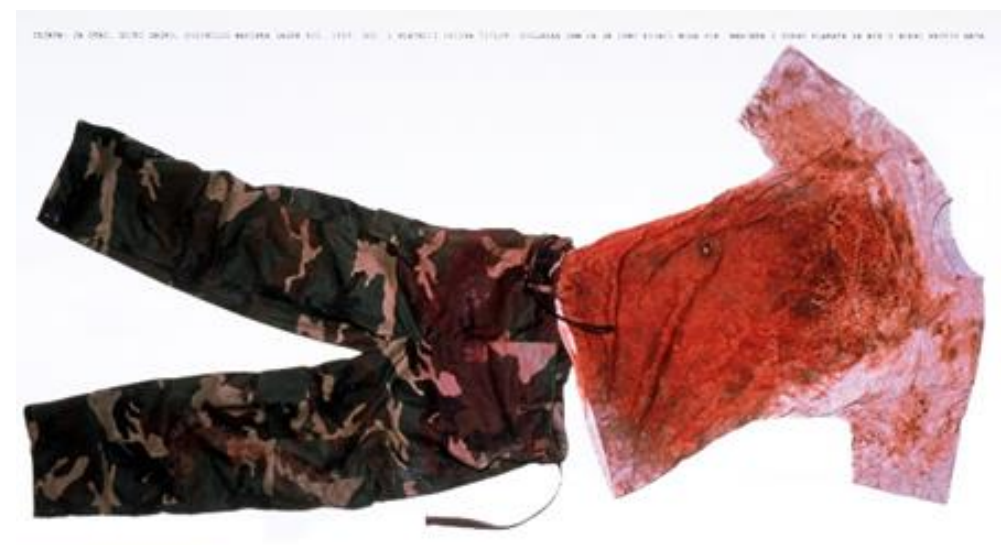

\section{UNITEO COOORS
OF BENETION.}

Figure 15. P/E 1994, 'Soldato bosniaco' (Bosnian soldier). Photo: Oliviero Toscani. (C) Benetton Group

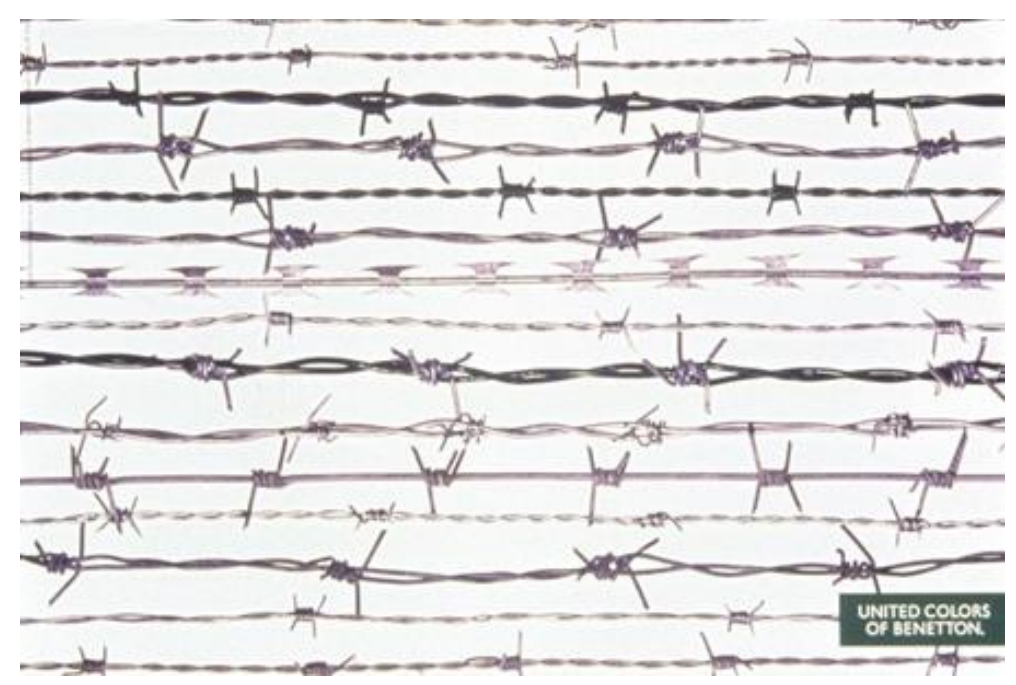

Figure 16. P/E 1995, 'Filo spinato' (Barbed wire). Photo: Oliviero Toscani. (C) Benetton Group 


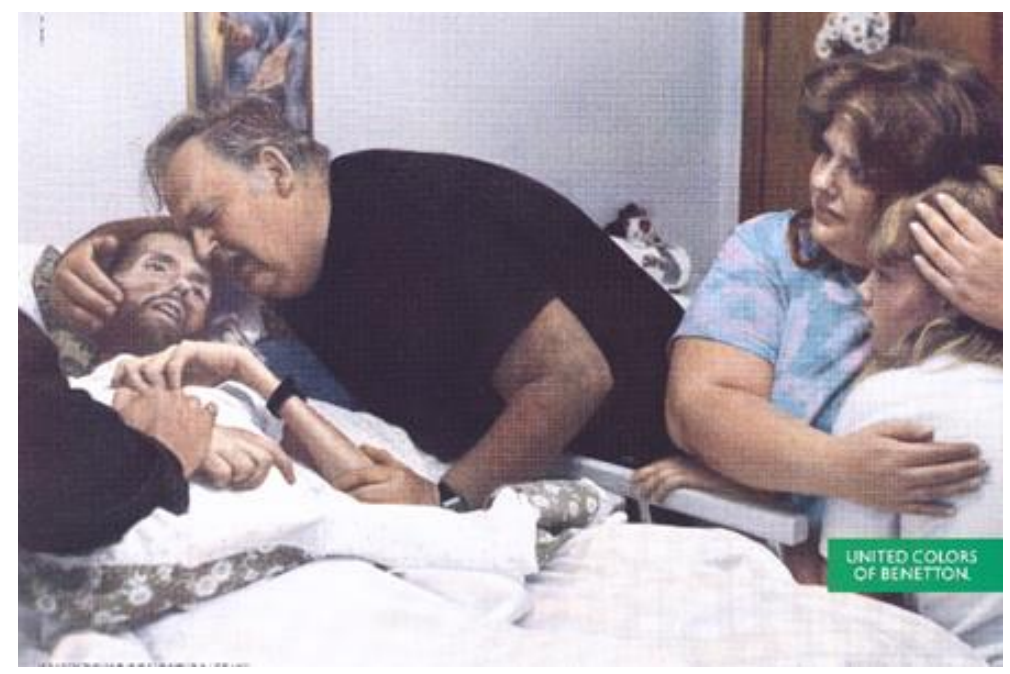

Figure 17. P/E 1992, 'AIDS - David Kirby'. Concept: Oliviero Toscani. Photo: Thérèse Frare. (C) Benetton Group

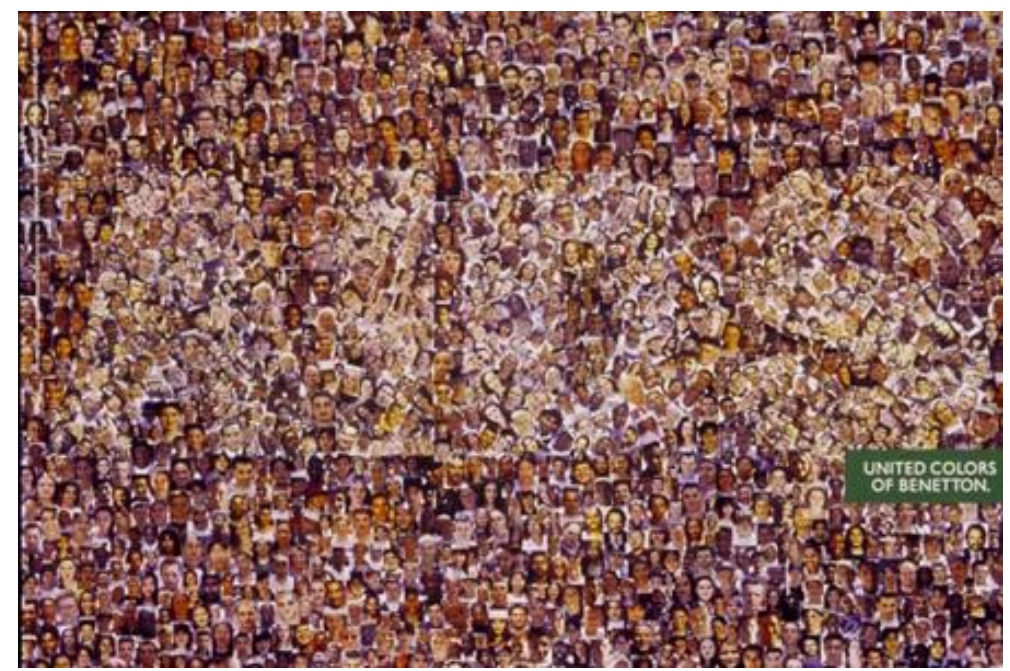

Figure 18. A/I 1993, 'AIDS - Facce' (AIDS - FAces). Photo: Oliviero Toscani. (C) Benetton Group 


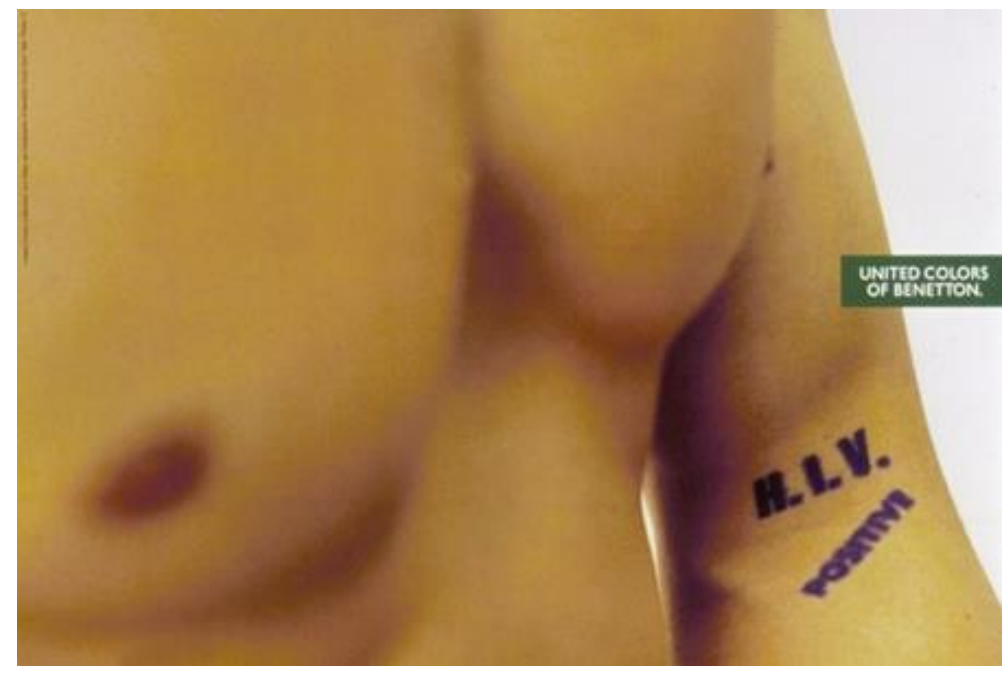

Figure 19. A/I 1993, 'HIV - Positivo' (HIV - Positive). Photo: Oliviero Toscani. (C) Benetton Group

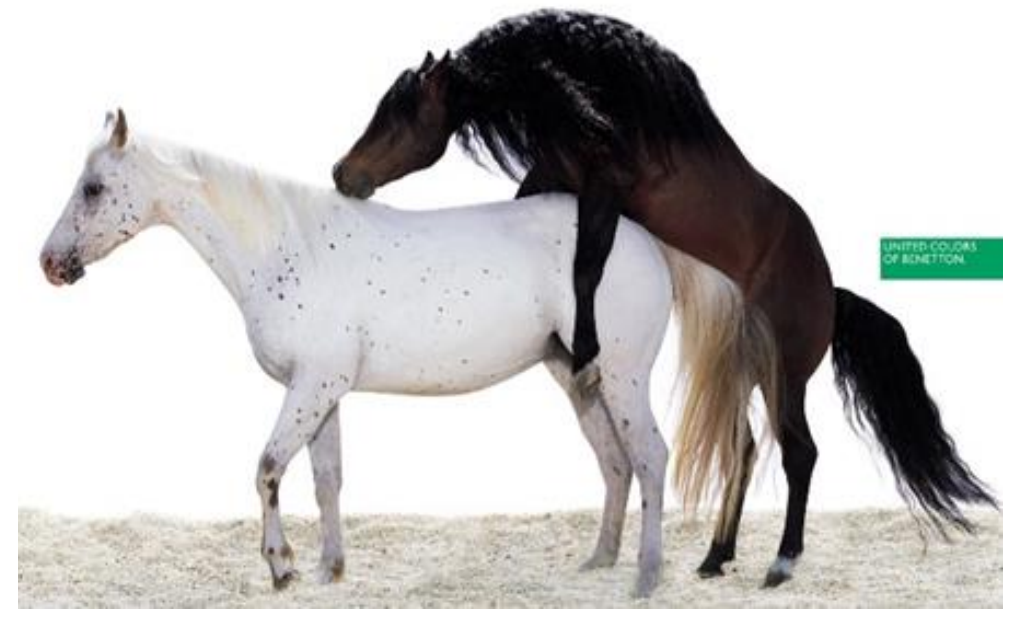

Figure 20. P/E 1996, 'Cavalli' (Horses). Photo: Oliviero Toscani. (C) Benetton Group 


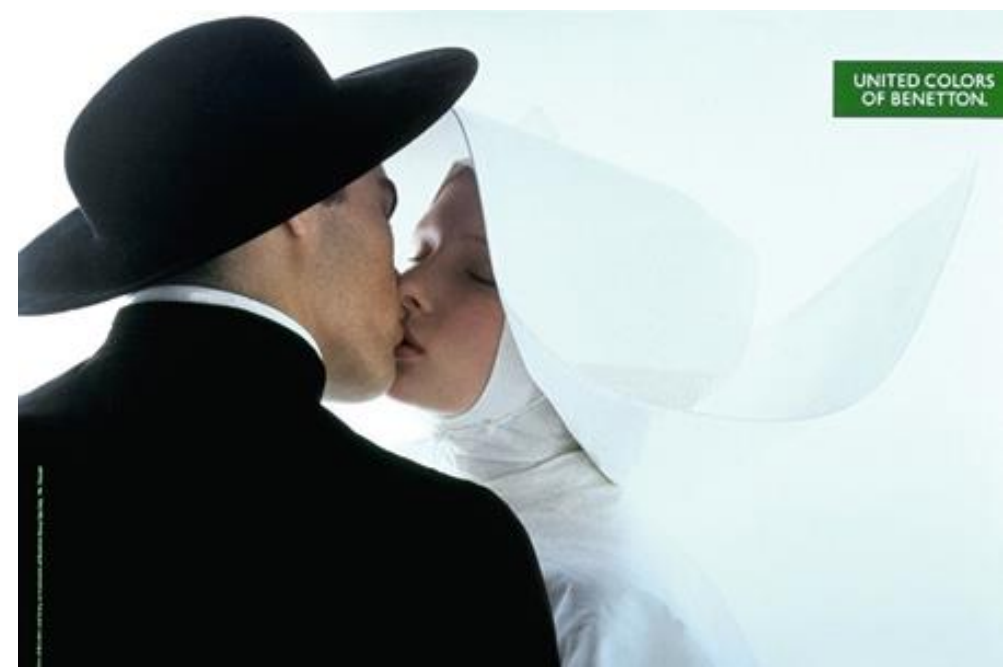

Figure 21. A/I 1991, 'Prete e suora' (Priest and nun). Photo: Oliviero Toscani. (C) Benetton Group

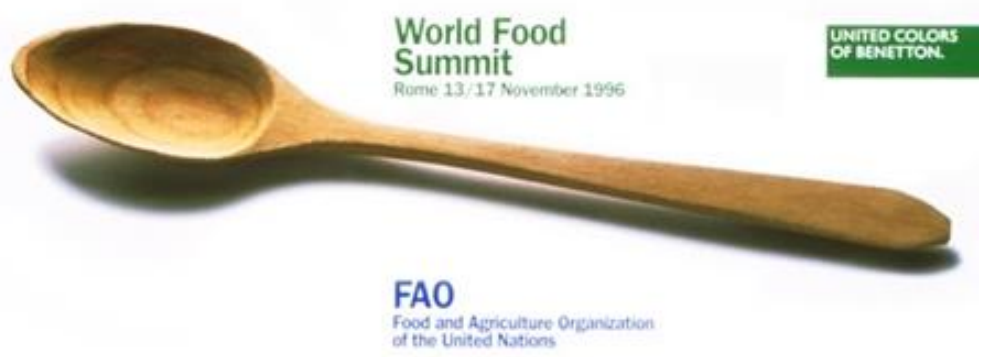

Figure 22. A/I 1996, 'Cucchiaio - FAO' (Spoon - FAO). Photo: Oliviero Toscani. (C) Benetton Group 


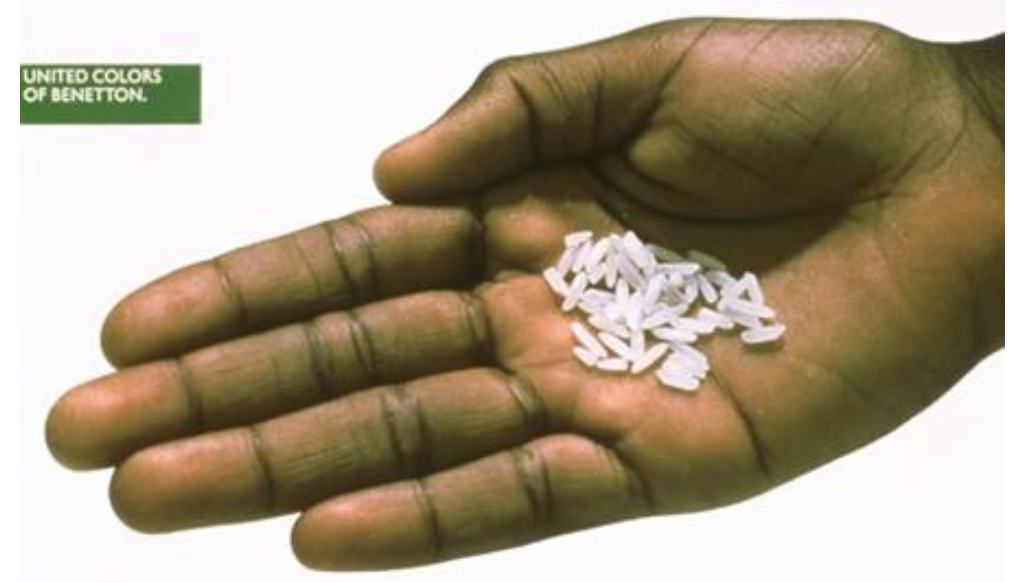

Figure 23. P/E 1997, 'Mani con riso' (Hand with rice).

Photo: Oliviero Toscani. (C) Benetton Group

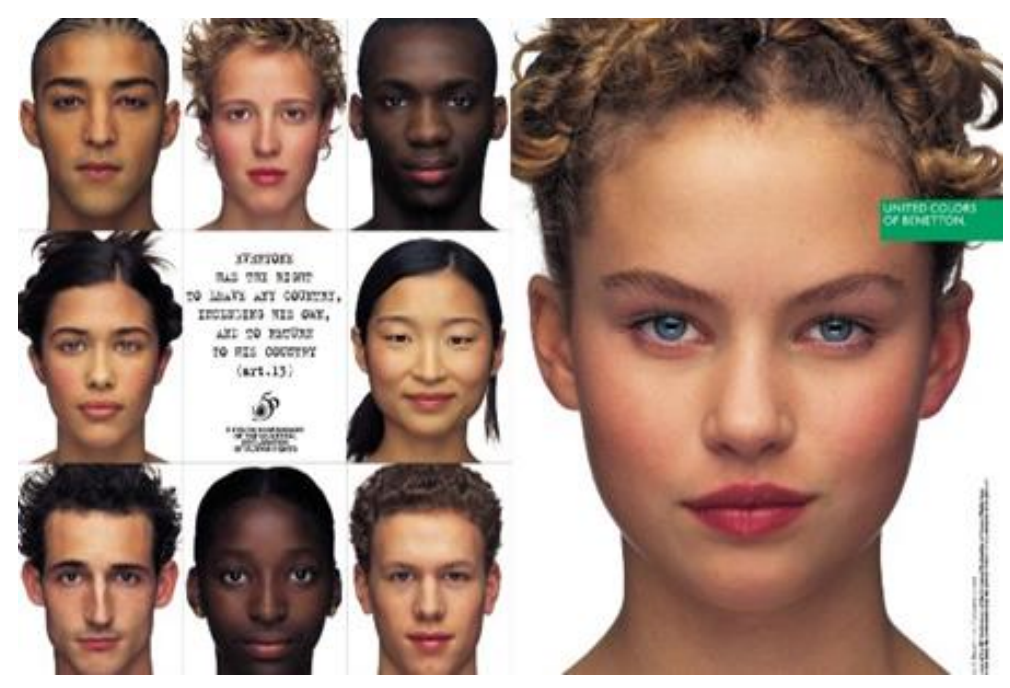

Figure 24. P/E 1998, 'Dichiarazione universale diritti dell'uomo - UN' (Universal Declaration of Human Rights UN). Photo: Oliviero Toscani. (C) Benetton Group 